\begin{tabular}{|l|l|l|}
\hline \multicolumn{2}{|c|}{ PublisherInfo } \\
\hline \hline PublisherName & $:$ & BioMed Central \\
\hline \hline PublisherLocation & $:$ & London \\
\hline \hline PublisherImprintName & $:$ & BioMed Central \\
\hline \hline
\end{tabular}

\title{
Genetic classification of lung tumors
}

\begin{tabular}{|l|l|l||}
\hline \multicolumn{2}{|c|}{ ArticleInfo } \\
\hline \hline ArticleID & $:$ & 4259 \\
\hline \hline ArticleDOI & $:$ & $10.1186 /$ gb-spotlight-20011123-01 \\
\hline \hline ArticleCitationID & $:$ & spotlight-20011123-01 \\
\hline \hline ArticleSequenceNumber & $:$ & 330 \\
\hline \hline ArticleCategory & $:$ & Research news \\
\hline ArticleFirstPage & $:$ & 1 \\
\hline \hline ArticleLastPage & $:$ & 2 \\
\hline \hline & & RegistrationDate : 2001-11-23 \\
ArticleHistory & $:$ & OnlineDate $\quad$ 2001-11-23 \\
\hline \hline ArticleCopyright & $:$ & BioMed Central Ltd2001 \\
\hline \hline ArticleGrants & $:$ & \\
\hline \hline ArticleContext & $:$ & 130592211 \\
\hline \hline
\end{tabular}




\section{Tudor Toma}

Email: t.toma@ic.ac.uk

The microscopic distinction of lung cancers into squamous, large cell, small cell, and adenocarcinoma gives essential information about the prognosis of the disease. Two papers in the November 20 Proceedings of the National Academy of Sciences, show that DNA microarray studies of crudely dissected lung tumors can be used to detect tumor subtypes that correlate with biological and clinical phenotypes.

Mitchell Garber and colleagues from Stanford University School of Medicine used 24,000-element cDNA microarrays to analyze the global gene expression profiles for 67 human lung tumors of 56 patients. They found specific patterns of gene expression that correspond to the major morphological classes of lung tumors. In addition, the gene expression patterns made possible the subclassification of adenocarcinoma into subgroups that correlated with the degree of tumor differentiation and patient survival (Proc Natl Acad Sci USA 2001, 98:13784-13789).

In a second paper, Arindam Bhattacharjee and colleagues from Harvard Medical School report an mRNA gene expression analysis of 186 human carcinomas from the lung, which showed further evidence for biologically distinct subclasses of lung adenocarcinoma (Proc Natl Acad Sci USA 2001, 98:13790-13795).

These results provide "extensive and detailed support for the idea that gene-expression-based classification of tumors will soon become clinically useful for cancer of the lung," concluded Garber et al. Such an advance would enable a clinician to address the tumor more effectively by administering a specific suite of treatments.

\section{References}

1. Stanford University School of Medicine, [http://www.med.stanford.edu/]

2. Garber ME, Troyanskaya OG, Schluens K, Petersen S, Thaesler Z, Pacyna-Gengelbach M, van de Rijn M, Rosen GL, Perou CM, Whyte RI, et al.: Diversity of gene expression in adenocarcinoma of the lung. Proc Natl Acad Sci USA 2001, 98:13784-13789., [http://www.pnas.org/cgi/content/abstract/98/24/ 13784]

3. Harvard Medical School, [http://www.hms.harvard.edu/]

4. Bhattacharjee A, Richards WG, Staunton J, Li C, Monti S, Vasa P, Ladd C, Beheshti J, Bueno R, Gillette M, et al:: Classification of human lung carcinomas by mRNA expression profiling reveals distinct adenocarcinoma subclasses. Proc Natl Acad Sci USA 2001, 98:13790-13795., [http://www.pnas.org/cgi/content/abstract/98/24/13790]

This PDF file was created after publication. 